\title{
Egypt COVID-19: Assessment of Knowledge, Attitudes and Practices among the General Population: Cross-Sectional Study
}

\section{Yasmin Husseiny Hassan Hussein ${ }^{1 *}$}

${ }^{1}$ Lecturer in Family Medicine Department, Faculty of Medicine, Zagazig University, Egypt.

\begin{abstract}
:
Background: Egypt has adopted exceptional preventive measures to control COVID-19. People's knowledge, attitudes, and practices towards this health problem influences their compliance with preventive strategies. Objectives: The present research assesses the level of knowledge, attitudes, and practices (KAP) regarding COVID-19 among the general population in Sharkia Governorate, Egypt. Methods: A cross-sectional survey was performed between May 28 and June 11, 2020. The respondents were invited to fulfill and submit an online survey created by Google Forms. The knowledge questionnaire included 13 items related to symptoms, transmission, and preventive measures of the disease. The participants' attitudes and practices included questions about their confidence in Egypt if it will win the fight against COVID-19 as well as the appropriate hand washing measures. Results: The mean knowledge score was 11.16, and the correct response rate for the knowledge questionnaire was $85.8 \%$. More than half of the participants were confident that Egypt will win the fight against the disease. Also, most of them practice appropriate hand washing measures. The average knowledge score was significantly lower among older, low education, rural, non-working, and low socioeconomic groups. Multivariate logistic regression analyses revealed that the COVID-19 knowledge score (OR: 0.72-1.16, $\mathrm{P}<0.001$ ) was significantly linked to a reduced probability of non-optimistic attitudes and unhealthy practices regarding COVID-19. Conclusions: Overall, the participants had a high level of knowledge, sound practices, and were not optimistic concerning COVID-19. More efforts are needed to focus the health education strategies on the low-knowledge groups reported in this study.
\end{abstract}

Keywords Hand washing, Mask, Pandemic, Prevention

\section{Introduction:}

At the end of 2019, coronavirus disease (COVID-19) was discovered in Wuhan, China. The causative agent is a highly infectious virus, finally called coronavirus 2 severe acute respiratory syndrome (SARSCoV-2). On March 11, the World Health Organization (WHO) declared COVID-19 as a pandemic, highlighting more than 118,000 cases in more than 110 countries and territories around the world and the continuing risk of further global spread. ${ }^{(1)}$

Most COVID-19 patients suffer from fever as well as typical respiratory symptoms and signs such as non-productive cough and shortness of breath, fatigue, and myalgia. (2,3) Half of the patients have gastrointestinal symptoms, mainly diarrhea, in addition to respiratory symptoms; however, it is rarely presented by gastrointestinal symptoms alone. ${ }^{(4)}$ Also, loss of smell or taste sensation and other symptoms are powerful indicators of COVID-19 infection. ${ }^{(5)}$

COVID-19 can be transmitted rapidly through the close contact with an infected person. ${ }^{(6,7)}$ The elderly and people with comorbidities are more vulnerable to 
infection and also more subjected to experiencing serious illness which is associated with acute respiratory distress syndrome (ARDS) and cytokine storms. ${ }^{\left({ }^{8}\right)}$

Egypt recorded the first case of COVID19 on February $14^{\text {th }} 2020$ involving one tourist from China. The number of cases has increased steadily, with an accelerated increase in cases in May 2020, but the Egyptian government has been vigilant in monitoring the situation and continued to develop proactive steps in line with the WHO guidelines ${ }^{(9)}$ such as restricting people's movements from $7 \mathrm{PM}$ to $6 \mathrm{AM}$, suspension of international air traffic in all Egyptian airports, and general lockdown of shops, malls, schools and universities.

The best way to restrict virus transmission is primary prevention by effective infection control measures. The success or failure of these control measures depends mainly on the public adherence which is affected by the population's KAP towards COVID-19.(10)

Understanding the public awareness about COVID-19 in Egypt is very important for action targeting stumbling blocks in problem management, especially during the rapid rise phase. Knowledge and attitudes towards infectious pandemic diseases have a direct impact on the level of panic among the population which interferes with efforts and attempts to prevent the disease spread. The present research assesses the level of KAP regarding COVID-19 among the general population in Sharkia Governorate, Egypt.

\section{Methods:}

A cross-sectional survey was conducted on the general Egyptian population of Sharkia governorate between May 28, 2020 and June 11, 2020. Based on the most recent Egyptian census, Sharkia governorate ranked third in the country in terms of population density, with a population of $7,555,703 .{ }^{(11)}$ A calculated sampling technique was used to select participants. To the best of our knowledge, at the time of sample size calculation, no published research reported the level of KAP about COVID-19 among Egyptians. Sample size was estimated using an online open epi program at confidence level of $99 \%$, a confidence limit of a design effect of 1 , and anticipated frequency of good knowledge of $50 \%$ to obtain the largest sample size to be 663. ${ }^{(12)}$ Therefore, the survey gateway was closed at the end of the 15 th day as the number of respondents exceeded the calculated sample.

The study included participants living in Sharkia from both sexes with an average age of 18 years and older who approved their involvement in the research. Due to the restricted movements and general lockdown in Egypt in this critical situation 
to achieve social distancing, respondents were invited to fulfill and submit an online survey created by Google Forms. On the first page of the Google form, the respondents were clearly informed about the study objectives and methodology in simple Arabic language. To avoid the duplication of responses for ensuring the validity of data, the option of "Allow only one response per user" was activated while creating the form. A questionnaire link was shared with groups of Sharkia residents on Facebook and WhatsApp.

A predesigned questionnaire was used for data collection based on a study in China. ${ }^{(13)}$ It consisted of the following main parts: 1) Socio-demographic level assessment, ${ }^{(14)}$ 2) knowledge measurement, 3) attitude assessment, and 4) questions about participants' practices to restrict COVID-19 transmission. Thirteen items measure the participant's knowledge about nature and symptoms (items 1-5), mode of transmission (items 6-8), and preventive measures (items 9-13) of the disease.

The participants were asked to reply with "yes" or "no" or "do not know" as an additional option. One point was given to the correct answer and zero was given to the wrong/uncertain "do not know" answer. The total score of knowledge ranged from zero to 13 , with a higher score reflecting good knowledge.
Regarding the assessment of attitudes, respondents answered "agree", "disagree", or "do not know" that the pandemic would be well controlled. Also, participants were asked about their confidence in Egypt if it would win the fight against COVID-19 (yes or no). Regarding practices, participants answered either "yes" or" no" as to how much they stopped going to crowded locations, used a face mask, and whether they followed hand washing instructions.

The reliability of the knowledge questionnaire was assessed by measuring its internal consistency. It demonstrated a good level of reliability (Cronbach's alpha = 0.83). (15) The questionnaire was checked and validated for content and relevance by the author and two external public health and family medicine professors. The questionnaire was submitted to participants in the Arabic language; it was translated from English to Arabic by the researcher then translated back to English after the respondents submitted it to verify the meaning of the data.

A pilot study was conducted on 20 participants to detect any difficulties and test the content validity and reliability of the questionnaire after translation. The sample included in the pilot study was excluded from the main sample because of the changes that were done in the final version of the questionnaire. 
The participants were informed of the rationale and objectives of the study and reassured that their personal information and responses are confidential. The submission of the Google response form was considered as a consent to be involved in the research. The participation of respondents was fully consensual, anonymous, and voluntary.

The collected data were entered to and analyzed by computer using Statistical Package for Social Sciences (SPSS) software (Statistical Package for the Sociable Sciences, version 25, SPSS Inc. Chicago, IL, USA). ${ }^{(16)}$

Data were presented in tables as frequencies, proportions, mean and standard deviation. As appropriate, independent samples t-test, one-way analysis of variance (ANOVA), or Chi-square tests were used to compare knowledge scores, attitudes, and practices of different participants according to socio-demographic characteristics. Multivariate logistic regression analyzes were used to identify predictors of participants' attitudes and practices. The Hosmer-Lemeshow test is used to determine the goodness of fit of the model.

\section{Results:}

Seven hundred and sixty-nine individuals submitted the survey. The total knowledge score for COVID-19 ranged from $1-13$ with a mean of $11.16 \pm 2.16$, and the correct response rate for the questionnaire was $85.8 \%(11.16 / 13 * 100)$. About $76.9 \%$ of the respondents reported a total knowledge score above 10 , reflecting a satisfactory level of COVID-19 knowledge (Table 1).

Regarding the socio-demographic characteristics of the respondents, almost two-thirds $(61.6 \%)$ were females and married (68.8\%). Approximately half of the participants (41.7\%) were of age 30-39 years old and working (46.6\%). More than half of the participants were of middle socioeconomic status $(57.5 \%)$, urban residents $(58.9 \%)$, and university graduates (71\%), (Table 2).

The study revealed that respondents of age $\geq 50$ years old $(\mathrm{P}<0.001)$, low socioeconomic status $(\mathrm{P}<0.001)$, high school or below education $(\mathrm{P}<0.001)$, not working $(\mathrm{P}<0.001)$, and rural residents $(\mathrm{P}<0.001)$ got a significantly low knowledge score (Table 2).

About half of the participants believed that COVID-19 would be well controlled (Table 1). This attitude was significantly associated with participants' age $(\mathrm{P}<0.05)$, education $\quad(\mathrm{P}<0.01)$ and residence $(\mathrm{P}<0.001)$. Also, the total COVID-19 knowledge score was significantly lower among participants who answered with 
"disagree" or "I do not know" than those who answered with "agree" $(\mathrm{P}<0.001)$ (Table 3).

More than half of the participants (60.3\%) had the confidence that Egypt can win the fight against the disease (Table 1). This attitude was significantly associated with participants' age $(\mathrm{P}<0.001)$, education $(\mathrm{P}<0.01)$, occupation $(\mathrm{P}<0.01)$, and total knowledge score of COVID-19 $(\mathrm{P}<0.001)$ (Table 3).

Most of the respondents (77.4\%) stated that they avoid visiting crowded locations, wear masks when going outside $(82.2 \%)$, and practice hand washing measures properly $(87.8 \%)$ (Table 1).

The practice of going to crowded places was significantly associated with sex $(\mathrm{P}<0.001)$, level of education $(\mathrm{P}<0.01)$, occupation $(\mathrm{P}<0.05)$, and total COVID-19 knowledge score $(\mathrm{P}<0.001)$ of participants. Wearing face masks was significantly more prevalent among females $(\mathrm{P}<0.05)$, participants of age group from 30 to 39 years old $(\mathrm{p}<0.001)$, married $(\mathrm{P}<0.01)$, postgraduate educated $(\mathrm{P}<0.001)$, working $(\mathrm{P}<0.001)$, those of high socioeconomic status $(\mathrm{P}<0.001)$, higher total COVID-19 knowledge score $(\mathrm{P}<0.001)$, and urban residents $(\mathrm{P}<0.001)$. The results of the study showed that the participants of age from 30 to 39 years old ( $\mathrm{p}<0.001)$, married $(\mathrm{P}<0.01)$, postgraduate educated $(\mathrm{p}<0.001)$, working $(\mathrm{P}<0.001)$, those of higher COVID-19 total knowledge score $(\mathrm{p}<0.001)$, and urban residents $(\mathrm{P}<0.01)$ are practicing appropriate hand washing measures compared to other participants; these results were statistically significant (Table 4).

The study reported a significant association between the participants' attitudes and practices towards COVID-19 where the participants with positive attitudes were more adherent to sound and healthy practices and also more committed to general protective measures (Table 4).

Regression analysis for predictors of attitudes and practices shows that the confidence that Egypt would win the fight against the disease was significantly associated with participants of age $\geq 50$ years old (OR: $0.73, \mathrm{P}=0.001$ ), those with high school or below education (OR: 2.37, $\mathrm{P}<0.001$ ), working (OR: 1.43, $\mathrm{P}=0.04$ ), and those who got higher COVID-19 knowledge score (OR: 0.81, $\mathrm{P}<0.001$ ).

Going to crowded places was significantly associated with male participants (OR: 2.31, $\mathrm{P}<0.001$ ), working ones (OR: 1.89, $\mathrm{P}=0.024$ ), and those who had lower COVID-19 knowledge (OR: $1.16, \mathrm{P}<0.001)$. Wearing the face mask was significantly associated with participants who had higher COVID-19 knowledge score (OR: 0.79, $\mathrm{P}<0.001)$ and those who 
had the confidence that Egypt will overcome the problem (OR: $3.48, \mathrm{P}<0.001$ ).

Participants who were married (OR: 2.36, $\mathrm{P}<0.013)$, got high COVID-19 knowledge score (OR: 0.72, $\mathrm{P}<0.001)$, had positive attitudes of COVID-19 control and confidence that Egypt will win the fight against the disease (OR: $1.93, \mathrm{P}<0.001$ and OR: 3.42, $\mathrm{P}<0.001$, respectively) were more committed with proper hand-washing measures (Table 5). A non-significant Hosmer-Lemeshow test indicates a good fit model.

\section{Discussion:}

COVID-19 is a major public health threat; it is considered as one of the greatest challenges the world has faced. Countries are racing to slow the spread of the disease, and preventive measures play a key role in this issue. Public commitment to prevention strategies is strongly influenced by the population's KAP to the disease.

The average COVID-19 knowledge score among the current study participants is $11.16 \pm 2.16$ and the overall correct answer rate is of $85.8 \%$, indicating good knowledge. This score is higher than the previous KAP study on COVID-19 in Malaysia where participants had a correct answer rate of $80.5 \%{ }^{(17)}$ This finding is not surprising as most of the study participants had university degree education or above. Participants also gain awareness and knowledge through various means of communication used by the Egyptian Ministry of Health (MOH). Moreover, on the $9^{\text {th }}$ of April 2020, MOH launched the "Health Egypt" application to raise awareness of the disease.

The results of the current study show that knowledge among older people $(\geq 50$ years of age), rural residents, non-workers, and those with low levels of education and socioeconomic status was significantly lower compared to other participants. This was consistent with the findings of other studies in Egypt and India. ${ }^{(18,19)}$ The level of knowledge towards communicable diseases is directly proportional to the educational and social levels of participants. ${ }^{(20)}$ The results of the study shed light on these categories that more efforts should be made to address any technical or financial barriers that interfere with the delivery of health education messages.

Concerning attitudes, participants were not optimistic about COVID-19, and this attitude was significantly more prevalent among younger participants, those living in urban areas, those with postgraduate degree education, and those with lower knowledge scores. This observation is consistent with the results of a study in the United States which stated that individuals were inclined to experience emotional problems such as 
anxiety and fear during a global epidemic that directly affect their attitudes. ${ }^{(21)}$

The results of the study showed that more than half of the participants had the confidence that Egypt can win the fight. This finding was significantly more prevalent among older participants $(\geq 50$ years old), workers, and those with high school or below education, as well as the participants who got higher knowledge scores. These results support the findings of previous studies which strongly correlated increased knowledge with reasonable confidence and optimistic pandemic attitudes. $^{(22)}$

The high level of COVID-19 knowledge among study participants is translated into sound and healthy practices; the practices of the participants are very prudent. This is in concordance with the results of a study conducted in Saudi Arabia ${ }^{(23)}$ and Bangladesh. ${ }^{(24)}$ The study's respondents adopted the sound and healthy practices as a consequence of the health education strategies of the Egyptian health authorities to improve public understanding of the disease and influence behavioral transformation.

The multivariate logistic regression analysis has shown that knowledge scores and attitudes of the participants are highly significant determinants of their practices as higher knowledge scores and positive attitudes are associated with higher-good and safe practices. A similar association between the knowledge about the disease and adherence to preventive practices has been reported in Egypt in the case of Hepatitis C virus, ${ }^{(25)}$ Saudi Arabia oin the case of MERS-CoV, (26), and Pakistan in the case of Dengue Fever transmission. ${ }^{(27)}$

The study findings revealed that sex and occupation are highly significant predictors for the practices of the respondents as males and workers have reported going to crowded places in recent days. This is consistent with other studies conducted on SARS and MERS-COV which have shown that males are significantly less likely to take preventive measures than females. ${ }^{(28-}$ ${ }^{30)}$ It also supports the results of a previous Egyptian study which reported that $61 \%$ of COVID-19 cases in Egypt were males versus $39 \%$ cases in females. ${ }^{(31)}$

The invitation of the participants via an online survey was the main limitation of the study as it permitted only those who can read and have access to the internet to participate.

\section{Conclusion:}

The study participants had a high level of knowledge, negative attitudes, and sound practices concerning COVID-19. Higher knowledge is linked to positive attitudes and safe practices. Knowledge was lower among older, rural, non-workers, low 
education, and low socioeconomic groups. Health education campaigns about the nature and mode of transmission of COVID-19 as well as the importance of different protective strategies are required, especially for the groups with a low level of knowledge reported in the current study.

\section{Declarations:}

Competing interests: There are no known conflicts of interest associated with this publication.

Funding: There has been no financial support for this work that could have influenced its outcome.

Acknowledgments: The author would like to thank the participants for their help to accomplish this work.

\section{References:}

1. World Health Organization. Coronavirus disease 2019 (COVID-19): Situation reports.Available:https://www.who.int/e mergencies/diseases/novel-coronavirus2019/situation-reports [Accessed June 2020].

2. Riou J, Althaus CL. Pattern of early human-to-human transmission of Wuhan 2019 novel coronavirus (2019nCoV), December 2019 to January 2020. Euro surveillance 2020; 25: 2000058.

3. Chan JF-W, Yuan S, Kok K-H, et al. A familial cluster of pneumonia associated with the 2019 novel coronavirus indicating person-to-person transmission: a study of a family cluster. Lancet 2020; 395: 514-523.

4. Pan L, Mu M, Yang $\mathrm{P}$ et al. Clinical Characteristics of COVID-19 Patients With Digestive Symptoms in Hubei, China: A Descriptive, Cross-Sectional, Multicenter Study. Am J Gastroenterol. 2020 May;115(5):766-773. doi: 10.14309/ajg.0000000000000620.

PMID: 32287140 ; $\quad$ PMCID: PMC7172492.

5. Menni C, Valdes AM, Freidin MB, et al. Real-time tracking of self-reported symptoms to predict potential COVID19. Nat Med 2020.

6. Phan LT, Nguyen TV, Luong QC, et al. Importation and human-to-human transmission of a novel coronavirus in Vietnam. N Engl J Med, 2020; 382: 872-874.

7. Parry J. China coronavirus: cases surge as official admits human to human transmission. BMJ. 2020 Jan 20;368:m236. doi: 10.1136/bmj.m236. PMID: 31959587.

8. Guo YR, Cao QD, Hong ZS, et al. The origin, transmission and clinical therapies on coronavirus disease 2019 (COVID-19) outbreak - an update on the status. Military Medical Research, 2020; 7(1): 11.

9. Egyptian PM: COVID-19-daily-briefingEgypt-records-346-cases-8- 
deaths.Available:

https://www.egypttoday.com/Article/1/8 6646/COVID-19-daily-briefing-Egyptrecords-346-cases-8-deaths [Accessed June 2020].

10. Li JY, You Z, Wang Q, et al. The epidemic of 2019-novel-coronavirus (2019-nCoV) pneumonia and insights for emerging infectious diseases in the future. Microbes and Infection, 2020; 22(2): 80-85.

11. Capmas.gov.eg.Available:http://capmas .gov.eg/Pages/populationClock.aspx [Accessed May 2020].

12. Open epi. Open source epidemiologic statistics for public health, version 3.01, updated

06/04/2013.Available:http://www.opene pi.com/Menu/OE_Menu.htm [Accessed June 2020].

13. Zhong BL, Luo W, Li HM, et al. Knowledge, attitudes, and practices towards COVID-19 among Chinese residents during the rapid rise period of the COVID-19 outbreak: A quick online cross-sectional survey. International Journal of Biological Sciences, 2020; 16(10): 1745-1752.

14. Fahmy SI, Nofal LM, Shehata SF, et al. Updating indicators for scaling the socioeconomic level of families for health research. J Egypt Public

Health Assoc, 2015Mar1; 90(1): 1-7.

15. Taber KS. The Use of Cronbach's Alpha When Developing and Reporting Research Instruments in Science Education. Research in Science Education, 2018; 48: 1273-1296.

16. IBM. (2017). IBM SPSS Statistics for Windows, Version 25. Armonk, NY: IBM Corp. http://www01.ibm.com/support/docview.wss?uid=s wg27049428. [Accessed August 2020].

17. Azlan AA, Hamzah MR, Sern TJ, et al. Public knowledge, attitudes and practices towards COVID-19: A crosssectional study in Malaysia. PLoS ONE 2020; 15(5): e0233668.

18. Abdelhafiz AS, Mohammed Z, Ibrahim ME, et al. Knowledge, Perceptions, and Attitude of Egyptians Towards the Novel Coronavirus Disease (COVID19) J Community Health 2020; 1-10.

19. Roy D, Tripathy S, Kar S, et al. Study of knowledge, attitude, anxiety \& perceived mental healthcare need in Indian population during COVID-19 pandemic. Asian Journal of Psychiatry, 2020; 51: 102083

20. Bawazir A, Al-Mazroo E, Jradi H et al. MERS-CoV infection: mind the public knowledge gap. J Infect Public Health, 2018; 11: 89-93. 
21. Blendon RJ, Benson JM, DesRoches CM.et al. The public's response to severe acute respiratory syndrome in Toronto and the United States. Clin Infect Dis, 2004; 38: 925-931.

22. Shi Y, Wang J, Yang $\mathrm{Y}$ et al. Knowledge and attitudes of medical staff in Chinese psychiatric hospitals regarding COVID-19. Brain Behav Immun Health, 2020; 4: 100064.

23. Al-Hanawi MK, Angawi K, Alshareef $\mathrm{N}$ et al. Knowledge, Attitude and Practice Toward COVID-19 Among the Public in the Kingdom of Saudi Arabia: A Cross-Sectional Study. Front. Public Health, 2020; 8: 217.

24. Rahman A, Sathi NJ. Knowledge, Attitude, and Preventive Practices toward COVID-19 among Bangladeshi Internet Users. Electron $\mathrm{J}$ Gen Med 2020; 17(5): em245.

25. Mohamed D, Khattab M, Labeeb S et al. Knowledge, Attitude and Practice Regarding Hepatitis C among Patients' Family Caregivers in El Minia Governorate. Journal of High Institute of Public Health, 2010; 40(2): 391-407.

26. Nour MO, Babilghith AO, Natto HA et al. Knowledge, attitude and practices of healthcare providers towards MERS$\mathrm{CoV}$ infection at Makkah hospitals, KSA. International Research Journal of
Medicine and Medical Sciences, 2015; 3(4): 103-112.

27. Hafeez F, Akram W, Suhail A, Arshad M. Knowledge and attitude of the public towards dengue control in urban and rural areas of Punjab. Pak J Zool, 2012; 44(1): 15-21.

28. Leung G, Lam T, Ho $L$ et al. The impact of community psychological responses on outbreak control for severe acute respiratory syndrome in Hong Kong. J Epidemiol Community Health, 2003; 57(11): 857-863.

29. Moran KR, Del Valle SY. A metaanalysis of the association between gender and protective behaviors in response to respiratory epidemics and pandemics. PLoS ONE 2016; 11: 0164541.

doi:10.1371/journal.pone.0164541

30. Aldowyan N, Abdallah AS, ElGharabawy R. Knowledge, Attitude and Practice (KAP) Study about Middle East Respiratory Syndrome Coronavirus (MERS-CoV) among Population in Saudi Arabia. International Archives of Medicine, 2017: 10.

31. Hasab AA, ElGhitany EM, Ahmed NN. Situational analysis and epidemic modeling of COVID-19 in Egypt. Journal of High Institute of Public Health, 2020; 50(1): 46-51. 
Table (1): Knowledge, attitude, and practice towards COVID-19 among the participants (No.=769).

\begin{tabular}{|c|c|c|c|c|c|c|}
\hline \multicolumn{7}{|l|}{ Knowledge } \\
\hline \multirow[t]{2}{*}{ Items } & \multicolumn{2}{|c|}{ True } & \multicolumn{2}{|c|}{ False } & \multicolumn{2}{|c|}{$\begin{array}{l}\text { I do not } \\
\text { know }\end{array}$} \\
\hline & No. & $\%$ & No. & $\%$ & No. & $\%$ \\
\hline K1. COVID-19 caused by viral infection & 721 & 93.8 & 6 & 0.8 & 42 & 5.4 \\
\hline $\begin{array}{l}\text { K2. Fever, fatigue, dry cough, myalgia, and loss of smell and taste } \\
\text { sensations are typical clinical presentations of COVID-19 }\end{array}$ & 721 & 93.8 & 6 & 0.8 & 42 & 5.4 \\
\hline $\begin{array}{l}\text { K3. Unlike common cold, runny nose and sneezing are less } \\
\text { common for people with COVID- } 19 \text {. }\end{array}$ & 534 & 69.4 & 87 & 11.3 & 148 & 19.3 \\
\hline $\begin{array}{l}\text { K4. Currently, there is no reliable treatment for COVID-19, but } \\
\text { early symptomatic and supportive care will help most patients } \\
\text { recover from infection. }\end{array}$ & 684 & 88.9 & 12 & 1.6 & 73 & 9.5 \\
\hline $\begin{array}{l}\text { K5. Not all people with COVID-19 will progress to serious cases. } \\
\text { Particularly elderly people, those having chronic diseases, and } \\
\text { obese are most likely to develop serious illnesses. }\end{array}$ & 645 & 83.9 & 42 & 5.5 & 82 & 10.6 \\
\hline $\begin{array}{l}\text { K6. Eating or contacting wild animals can lead to infection with the } \\
\text { COVID-19 virus }\end{array}$ & 162 & 21.1 & 309 & 40.1 & 298 & 38.8 \\
\hline $\begin{array}{l}\text { K7. COVID-19 patients cannot transmit the virus to others when a } \\
\text { fever is absent }\end{array}$ & 80 & 10.4 & 647 & 84.1 & 42 & 5.5 \\
\hline $\begin{array}{l}\text { K8.The COVID-19 virus is spread by respiratory droplets of } \\
\text { infected individuals }\end{array}$ & 730 & 94.9 & 19 & 2.5 & 20 & 2.6 \\
\hline $\begin{array}{l}\text { K9. Wearing of facial masks will prevent infection with the } \\
\text { COVID-19 virus }\end{array}$ & 615 & 80 & 35 & 4.6 & 119 & 15.4 \\
\hline $\begin{array}{l}\text { K10. For children and young adults, it is not necessary to follow } \\
\text { strict preventive measures }\end{array}$ & 15 & 2 & 736 & 95.7 & 18 & 2.3 \\
\hline $\begin{array}{l}\text { K11. Avoiding the presence in crowded locations can prevent } \\
\text { infection with COVID-19 }\end{array}$ & 744 & 96.7 & 5 & 0.7 & 20 & 2.6 \\
\hline $\begin{array}{l}\text { K12. Isolation and treatment of COVID-19 cases are effective ways } \\
\text { to reduce the spread of the disease }\end{array}$ & 754 & 98 & 3 & 0.4 & 12 & 1.6 \\
\hline $\begin{array}{l}\text { K13. Individuals who have contact with COVID-19 cases should be } \\
\text { isolated in a proper place promptly. In general, the observation } \\
\text { period is } 14 \text { days. }\end{array}$ & 739 & 96.1 & 4 & 0.5 & 26 & 3.4 \\
\hline $\begin{array}{l}\text { Total score } \\
\text { Min-Max } \\
\text { Mean } \pm \text { SD }\end{array}$ & \multicolumn{6}{|c|}{$\begin{array}{l}1-13 \\
11.16 \pm 2.16\end{array}$} \\
\hline \multicolumn{7}{|l|}{ Attitudes } \\
\hline \multirow{3}{*}{ A1. Do you think that COVID-19 would be successfully controlled? } & \multicolumn{2}{|c|}{ Agree } & \multicolumn{2}{|c|}{ Disagree } & \multicolumn{2}{|c|}{ I don't know } \\
\hline & No. & $\%$ & No. & $\%$ & No. & $\%$ \\
\hline & 337 & 43.8 & 167 & 21.7 & 265 & 34.5 \\
\hline \multirow{3}{*}{$\begin{array}{l}\text { A2. Do you have the confidence that Egypt will be able to win the } \\
\text { fight against COVID-19? }\end{array}$} & \multicolumn{3}{|c|}{ Yes } & \multicolumn{3}{|c|}{ No } \\
\hline & $\mathbf{N}$ & & $\%$ & $\mathbf{N}$ & $\%$ & \\
\hline & 464 & & 60.3 & 305 & 39 & \\
\hline \multicolumn{7}{|l|}{ Practices } \\
\hline \multirow[t]{2}{*}{ Items } & \multicolumn{3}{|c|}{ Yes } & \multicolumn{3}{|l|}{ No } \\
\hline & $\mathbf{N}$ & & $\%$ & $\mathbf{N}$ & $\%$ & \\
\hline P1. Have you recently gone to any crowded location? & 174 & & 22.6 & 595 & 77 & \\
\hline P2. Have you recently worn a mask when leaving home? & 867 & & 88.2 & 91 & 11 & \\
\hline $\begin{array}{l}\text { P3. Recently, have you often washed your hands with soap and } \\
\text { water for at least } 40 \text { seconds, particularly after being in a crowded } \\
\text { spot, or after nose-blowing, coughing, or sneezing? }\end{array}$ & 675 & & 87.8 & 94 & & \\
\hline
\end{tabular}


Table (2): Association between socio-demographic characteristics of the participants and their knowledge scores (No.=769)

\begin{tabular}{|c|c|c|c|c|c|}
\hline \multicolumn{2}{|c|}{ Characteristics } & $\begin{array}{c}\text { No. of } \\
\text { participants } \\
(\%)\end{array}$ & $\begin{array}{c}\text { Knowledge } \\
\text { score (mean } \pm \\
\text { SD) }\end{array}$ & $\mathbf{t} / \mathbf{F}$ & P-value \\
\hline \multirow[t]{2}{*}{ Gender } & - Male & $295(38.4)$ & $11.01 \pm 2.34$ & \multirow[t]{2}{*}{-1.482} & \multirow[t]{2}{*}{0.071} \\
\hline & - Female & 474 (61.6) & $11.25 \pm 2.03$ & & \\
\hline \multirow[t]{4}{*}{ Age group } & - $18-29$ & $312(40.6)$ & $11.06 \pm 1.99$ & \multirow[t]{4}{*}{9.479} & \multirow[t]{4}{*}{$<0.001 *$} \\
\hline & - 30-39 & $321(41.7)$ & $11.37 \pm 1.85$ & & \\
\hline & - 40-49 & $76(9.9)$ & $11.61 \pm 2.12$ & & \\
\hline & - $\geq 50$ & $60(7.8)$ & $9.90 \pm 3.61$ & & \\
\hline \multirow[t]{2}{*}{ Marital status } & - Not married & $240(31.2)$ & $11.13 \pm 1.93$ & \multirow[t]{2}{*}{-0.197} & \multirow[t]{2}{*}{0.147} \\
\hline & - Married & $529(68.8)$ & $11.17 \pm 2.25$ & & \\
\hline \multirow[t]{3}{*}{ Education } & $\begin{array}{l}\text { - High school } \\
\text { or below }\end{array}$ & $97(12.6)$ & $9.01 \pm 3.49$ & \multirow[t]{3}{*}{69.484} & \multirow[t]{3}{*}{$<0.001^{*}$} \\
\hline & $\begin{array}{l}\text { University } \\
\text { degree }\end{array}$ & $546(71.0)$ & $11.35 \pm 1.69$ & & \\
\hline & $\begin{array}{l}\text { Postgraduate } \\
\text { degree }\end{array}$ & $126(16.4)$ & $11.95 \pm 1.49$ & & \\
\hline \multirow[t]{2}{*}{ Occupation } & - Not working & $411(53.4)$ & $10.81 \pm 2.38$ & \multirow[t]{2}{*}{-4.767} & \multirow[t]{2}{*}{$<0.001^{*}$} \\
\hline & - Working & 358 (46.6) & $11.55 \pm 1.78$ & & \\
\hline \multirow{3}{*}{$\begin{array}{l}\text { Socioeconomic } \\
\text { status }\end{array}$} & - Low & $90(11.7)$ & $10.46 \pm 2.81$ & \multirow[t]{3}{*}{12.593} & \multirow[t]{3}{*}{$<0.001^{*}$} \\
\hline & - Middle & $442(57.5)$ & $11.02 \pm 2.19$ & & \\
\hline & - High & $237(30.8)$ & $11.67 \pm 1.63$ & & \\
\hline \multirow[t]{2}{*}{ Residence } & - Rural & $316(41.1)$ & $10.59 \pm 2.50$ & \multirow[t]{2}{*}{-6.211} & \multirow[t]{2}{*}{$<0.001 *$} \\
\hline & - Urban & 453 (58.9) & $11.55 \pm 1.78$ & & \\
\hline
\end{tabular}

*statistically significant 
Table (3): Association between socio-demographic characteristics of the participants and attitudes towards COVID-19 (No. =769)

\begin{tabular}{|c|c|c|c|c|c|c|}
\hline \multirow[t]{2}{*}{ Characteristics } & & \multicolumn{3}{|c|}{$\begin{array}{l}\text { COVID-19 will be controlled } \\
\text { successfully }\end{array}$} & \multicolumn{2}{|c|}{\begin{tabular}{|c|}
$\begin{array}{c}\text { Confidence that Egypt } \\
\text { would win the fight } \\
\text { against COVID-19 }\end{array}$ \\
\end{tabular}} \\
\hline & & Agree & Disa Igree & $\begin{array}{c}\text { I do not } \\
\text { know }\end{array}$ & Yes & No \\
\hline \multirow[t]{2}{*}{ Sex } & - Male & $\begin{array}{c}136 \\
(46.1 \%)\end{array}$ & $56(19 \%)$ & $103(34.9 \%)$ & $\begin{array}{c}176 \\
(59.7 \%)\end{array}$ & $\begin{array}{c}119 \\
(40.3 \%)\end{array}$ \\
\hline & - Female & $\begin{array}{c}201 \\
(42.4 \%)\end{array}$ & $\begin{array}{c}111 \\
(23.4 \%)\end{array}$ & $162(34.2 \%)$ & $\begin{array}{c}288 \\
(60.8 \%)\end{array}$ & $\begin{array}{c}186 \\
(39.2 \%)\end{array}$ \\
\hline \multirow[t]{4}{*}{ Age group } & - $18-29$ & $\begin{array}{c}132 \\
(42.3 \%) \\
\end{array}$ & $71(22.8 \%)$ & $109(34.9 \%)$ & $\begin{array}{c}178 \\
(57.1 \%) \\
\end{array}$ & $\begin{array}{c}134 \\
(42.9 \%) \\
\end{array}$ \\
\hline & - 30-39 & $138(43 \%)$ & $78(24.3 \%)$ & $105(32.7 \%)$ & $\begin{array}{c}189 \\
(58.9 \%) \\
\end{array}$ & $\begin{array}{c}132 \\
(41.1 \%) \\
\end{array}$ \\
\hline & - $40-49$ & $31(40.8 \%)$ & $15(19.7 \%)$ & $30(39.5 \%)$ & $\begin{array}{c}43 \\
(56.6 \%) \\
\end{array}$ & $33(43.4 \%)$ \\
\hline & - $\geq 50$ & $36(60 \%)$ & $3(5 \%)$ & $21(35 \%)^{*}$ & $54(90 \%)$ & $6(10 \%)^{* * *}$ \\
\hline \multirow[t]{2}{*}{ Marital status } & - Not married & $\begin{array}{c}114 \\
(47.5 \%) \\
\end{array}$ & $44(18.3 \%)$ & $82(34.2 \%)$ & $\begin{array}{c}139 \\
(57.9 \%) \\
\end{array}$ & $\begin{array}{c}101 \\
(42.1 \%) \\
\end{array}$ \\
\hline & - Married & $\begin{array}{c}223 \\
(42.2 \%) \\
\end{array}$ & $\begin{array}{c}123 \\
(23.3 \%) \\
\end{array}$ & $183(36.4 \%)$ & $\begin{array}{c}325 \\
(61.4 \%) \\
\end{array}$ & $\begin{array}{c}204 \\
(38.6 \%) \\
\end{array}$ \\
\hline \multirow[t]{3}{*}{ Education } & $\begin{array}{l}\text { - High school or } \\
\text { below }\end{array}$ & $46(47.4 \%)$ & $15(15.5 \%)$ & $36(37.1 \%)$ & $\begin{array}{c}63 \\
(64.9 \%) \\
\end{array}$ & $34(35.1 \%)$ \\
\hline & $\begin{array}{l}\text { - University } \\
\text { degree }\end{array}$ & $\begin{array}{c}255 \\
(46.7 \%) \\
\end{array}$ & $\begin{array}{c}110 \\
(20.1 \%)\end{array}$ & $181(33.2 \%)$ & $\begin{array}{c}341 \\
(62.5 \%) \\
\end{array}$ & $\begin{array}{c}205 \\
(37.5 \%) \\
\end{array}$ \\
\hline & $\begin{array}{l}\text { - Postgraduate } \\
\text { degree }\end{array}$ & $36(28.6 \%)$ & $42(33.3 \%)$ & \begin{tabular}{c}
\multirow{**}{*}{$(38.1 \%)$} \\
\end{tabular} & $\begin{array}{c}60 \\
(47.6 \%) \\
\end{array}$ & $66(52.4 \%)$ \\
\hline \multirow[t]{2}{*}{ Occupation } & - Not working & $\begin{array}{c}186 \\
(40.9 \%) \\
\end{array}$ & $98(23.8 \%)$ & $145(35.3 \%)$ & $\begin{array}{c}299 \\
(55.7 \%) \\
\end{array}$ & $\begin{array}{c}182 \\
(44.3 \%) \\
\end{array}$ \\
\hline & - Working & $\begin{array}{c}169 \\
(47.2 \%) \\
\end{array}$ & $69(19.3 \%)$ & $120(33.5 \%)$ & $\begin{array}{c}235 \\
(65.6 \%) \\
\end{array}$ & $\begin{array}{c}123 \\
(34.4 \%)^{* *}\end{array}$ \\
\hline \multirow[t]{3}{*}{$\begin{array}{l}\text { Socioeconomic } \\
\text { status }\end{array}$} & - Low & $38(42.2 \%)$ & $17(18.9 \%)$ & $35(38.9 \%)$ & $\begin{array}{c}56 \\
(62.2 \%) \\
\end{array}$ & $34(37.8 \%)$ \\
\hline & - Middle & $\begin{array}{c}192 \\
(43.4 \%) \\
\end{array}$ & $\begin{array}{c}101 \\
(22.9 \%)\end{array}$ & $149(33.7 \%)$ & $\begin{array}{c}254 \\
(57.5 \%) \\
\end{array}$ & $\begin{array}{c}188 \\
(42.5 \%) \\
\end{array}$ \\
\hline & - High & $107(45.1)$ & $49(20.7 \%)$ & $81(34.2 \%)$ & $154(65 \%)$ & $83(35 \%)$ \\
\hline \multirow[t]{2}{*}{ Residence } & - Rural & $\begin{array}{c}151 \\
(47.8 \%) \\
\end{array}$ & $44(13.9 \%)$ & $121(38.3 \%)$ & $\begin{array}{c}200 \\
(63.3 \%) \\
\end{array}$ & $\begin{array}{c}116 \\
(36.7 \%) \\
\end{array}$ \\
\hline & - Urban & $\begin{array}{c}186 \\
(41.1 \%) \\
\end{array}$ & $\begin{array}{c}123 \\
(27.2 \%) \\
\end{array}$ & $144(31.8 \%)$ & $\begin{array}{c}264 \\
(58.3 \%) \\
\end{array}$ & $\begin{array}{c}189 \\
(41.7 \%) \\
\end{array}$ \\
\hline \multicolumn{2}{|c|}{ COVID-19 knowledge score } & $11.3(1.8)$ & $10.9(1.5)$ & $10.7(2.5)$ & $11.4(1.8)$ & $10.8(2.5)$ \\
\hline
\end{tabular}

$* \mathrm{P}<0.05, * * \mathrm{P}<0.01, * * * \mathrm{P}<0.001$ 
Table (4): Comparison between participants' practices towards COVID-19 in terms of socio-demographic characteristics, knowledge, and attitudes (No.=769)

\begin{tabular}{|c|c|c|c|c|c|c|c|}
\hline \multirow[t]{2}{*}{ Characteristics } & & \multicolumn{2}{|c|}{$\begin{array}{c}\text { Going to a crowded } \\
\text { location }\end{array}$} & \multicolumn{2}{|c|}{ Mask usage } & \multicolumn{2}{|c|}{ Wash hands properly } \\
\hline & & Yes & No & Yes & No & Yes & No \\
\hline \multirow[t]{2}{*}{ Gender } & - Male & $99(33.6 \%)$ & $196(66.4 \%)$ & $252(66.4 \%)$ & $43(14.6 \%)$ & $252(85.4 \%)$ & $43(16.6 \%)$ \\
\hline & - Female & $75(15.8 \%)$ & $\begin{array}{c}399(84.2 \%) \\
* * *\end{array}$ & $426(89.9 \%)$ & $48(10.1 \%)^{*}$ & $423(89.2 \%)$ & $51(10.8 \%)$ \\
\hline \multirow[t]{4}{*}{ Age group } & - 18-29 & $71(22.8 \%)$ & $241(77.2 \%)$ & $254(81.4 \%)$ & $58(18.6 \%)$ & $254(81.4 \%)$ & $58(18.6 \%)$ \\
\hline & - 30-39 & $75(23.4 \%)$ & $246(76.6 \%)$ & $309(96.3 \%)$ & $12(3.7 \%)$ & $303(94.4 \%)$ & $18(5.6 \%)$ \\
\hline & - 40-49 & $13(17.1 \%)$ & $63(82.9 \%)$ & $67(88.2 \%)$ & $9(11.8 \%)$ & $70(92.1 \%)$ & $6(7.9 \%)$ \\
\hline & $\cdot \geq 50$ & $15(25 \%)$ & $45(75 \%)$ & $48(80 \%)$ & $12(20 \%)^{* * *}$ & $48(80 \%)$ & $12(20 \%)^{* * * *}$ \\
\hline \multirow[t]{2}{*}{ Marital status } & $\begin{array}{l}\text { - Not } \\
\text { married }\end{array}$ & $47(19.6 \%)$ & $193(80.4 \%)$ & $200(83.3 \%)$ & $40(16.7 \%)$ & $197(82.1 \%)$ & $43(17.9 \%)$ \\
\hline & - Married & $127(24 \%)$ & $402(76 \%)$ & $478(90.4 \%)$ & $51(9.6 \%)^{* *}$ & $478(90.4 \%)$ & $51(9.6 \%)^{* *}$ \\
\hline \multirow[t]{3}{*}{ Education } & $\begin{array}{l}\text { - High } \\
\text { school or } \\
\text { below }\end{array}$ & $33(34 \%)$ & $64(66 \%)$ & $73(73.2 \%)$ & $24(24.7 \%)$ & $73(75.3 \%)$ & $24(24.7 \%)$ \\
\hline & $\begin{array}{l}\text { University } \\
\text { degree }\end{array}$ & $120(22 \%)$ & $246(78 \%)$ & $485(88.8 \%)$ & $61(11.2 \%)$ & $482(88.3 \%)$ & $64(11.76 \%)$ \\
\hline & $\begin{array}{l}\text { - Postgradua } \\
\text { te degree }\end{array}$ & $21(16.7 \%)$ & $105(83.3 \%)^{* *}$ & $120(95.2 \%)$ & $6(4.8 \%)^{* * *}$ & $120(95.2 \%)$ & $6(4.8 \%)^{* * * *}$ \\
\hline \multirow[t]{2}{*}{ Occupation } & $\begin{array}{l}\text { - Not } \\
\text { working }\end{array}$ & $80(19.5 \%)$ & $331(80.5 \%)$ & $347(84.4 \%)$ & $64(15.6 \%)$ & $344(83.7 \%)$ & $67(16.3 \%)$ \\
\hline & - Working & $94(26.3 \%)$ & $264(73.7 \%)^{*}$ & $331(92.5 \%)$ & $2 \underset{* * *}{27.5 \%)}$ & $331(92.5 \%)$ & $2 \underset{* * *}{27(7.5 \%)}$ \\
\hline \multirow{3}{*}{$\begin{array}{l}\text { Socioeconomic } \\
\text { status }\end{array}$} & - Low & $23(25.6 \%)$ & $67(74.4 \%)$ & $69(76.7 \%)$ & $21(23.3 \%)$ & $74(82.2 \%)$ & $16(17.8 \%)$ \\
\hline & - Middle & $101(22.9 \%)$ & $341(77.1 \%)$ & $389(88 \%)$ & $53(12 \%)$ & $386(87.3 \%)$ & $56(12.7 \%)$ \\
\hline & - High & $50(21.1 \%)$ & $187(78.9 \%)$ & $220(92.8 \%)$ & $17 \underset{* * * *}{(7.2 \%)}$ & $215(90.7 \%)$ & $22(9.3 \%)$ \\
\hline \multirow[t]{2}{*}{ Residence } & - Rural & $81(25.6 \%)$ & $235(74.4 \%)$ & $261(82.6 \%)$ & $55(17.4 \%)$ & $264(83.5 \%)$ & $52(16.5 \%)$ \\
\hline & - Urban & $93(20.5 \%)$ & $360(79.5 \%)$ & $417(92.1 \%)$ & $36(\underset{* * *}{3.9 \%)}$ & $411(90.7 \%)$ & $42(9.3 \%)^{* *}$ \\
\hline \multicolumn{2}{|c|}{\begin{tabular}{|l|} 
COVID-19 knowledge score \\
\end{tabular}} & $10.5(3.1)$ & $11.4(1.7)^{* * *}$ & $11.4(1.8)$ & $9.3(3.4)^{* * *}$ & $11.4(1.7)$ & $9.1(3.6)^{* * *}$ \\
\hline \multicolumn{2}{|c|}{$\begin{array}{l}\text { COVID-19 will be } \\
\text { controlled successfully } \\
\text { - Agree } \\
\text { - Disagree } \\
\text { - I do not know }\end{array}$} & $\begin{array}{c}64(19) \\
52(31.1) \\
58(21.9)\end{array}$ & $\begin{array}{c}273(81) \\
115(68.9) \\
207(78.1) * *\end{array}$ & $\begin{array}{c}313(92.2) \\
142(85) \\
223(84.2)\end{array}$ & $\begin{array}{c}24(7.1) \\
25(15) \\
42(15.8)^{* *}\end{array}$ & $\begin{array}{l}325(96.4) \\
136(81.4) \\
214(80.8)\end{array}$ & $\begin{array}{c}12(3.6) \\
31(18.6) \\
51(19.2)^{* *}\end{array}$ \\
\hline \multicolumn{2}{|c|}{$\begin{array}{l}\text { Confidence that Egypt } \\
\text { would win the fight against } \\
\text { COVID-19 } \\
\text { Yes }\end{array}$} & $\begin{array}{l}94(20.3) \\
80(26.2)\end{array}$ & $\begin{array}{c}370(79.7) \\
225(73.8)^{*}\end{array}$ & $\begin{array}{l}437(94.2) \\
241(79)\end{array}$ & $\begin{array}{c}27(5.8) \\
64(21) * * *\end{array}$ & $\begin{array}{c}437(94.2) \\
238(78)\end{array}$ & $\begin{array}{c}27(5.8) \\
67(22) * * *\end{array}$ \\
\hline
\end{tabular}

$* \mathrm{P}<0.05, * * \mathrm{P}<0.01, * * * \mathrm{P}<0.001$ 
Table (5): Multivariate binary logistic regression analysis for predictors of attitudes and practices towards COVID-19

\begin{tabular}{|c|c|c|}
\hline Predictors & O.R (95\% C.I ) & P-value \\
\hline \multicolumn{3}{|c|}{ Confidence in Egypt winning the fight against COVID-19 } \\
\hline - Age group $(\geq 50)$ & $0.73(0.6-0.88)$ & 0.001 \\
\hline - Education (high school or below) & $2.37(1.71-3.28)$ & $<0.001$ \\
\hline - Occupation (working) & $1.43(1.02-2.01)$ & 0.04 \\
\hline - Total knowledge score (high) & $0.81(0.74-0.87)$ & $<0.001$ \\
\hline \multicolumn{3}{|l|}{ Hosmer and lemeshow test $=7.4, p$-value $=0.497$} \\
\hline \multicolumn{3}{|l|}{ P1. Going to a crowded location } \\
\hline - Gender (Male) & $2.31(1.58-3.38)$ & $<0.001$ \\
\hline - Occupation (work) & $1.89(1.14-3.15)$ & 0.024 \\
\hline - Total knowledge score (low) & $1.16(1.07-1.26)$ & $<0.001$ \\
\hline \multicolumn{3}{|l|}{ Hosmer and lemeshow test $=8.3, \mathrm{p}$-value $=0.41$} \\
\hline \multicolumn{3}{|l|}{ P2. Mask wearing } \\
\hline - Total knowledge score (high) & $0.79(0.71-0.87)$ & $<0.001$ \\
\hline - Trust in Egypt winning (yes) & $3.48(1.96-6.18)$ & $<0.001$ \\
\hline \multicolumn{3}{|l|}{ Hosmer and lemeshow test $=4.3, p$-value $=0.83$} \\
\hline \multicolumn{3}{|l|}{ P3. Hand washing } \\
\hline - Marital status (married) & $2.36(1.19-4.65)$ & 0.013 \\
\hline - Total knowledge score (high) & $0.72(0.63-0.81)$ & $<0.001$ \\
\hline - COVID-19 will be controlled successfully (yes) & $1.93(1.4-2.64)$ & $<0.001$ \\
\hline - Confidence in Egypt winning the fight (yes) & $3.42(2.01-5.81)$ & $<0.001$ \\
\hline
\end{tabular}




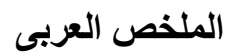

كوفيد-19 فى مصر : قياس المعارف والمواقف والممارسات عند عامة الناس: دراسة مقطعية

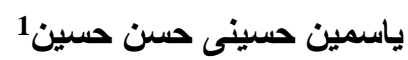
1 قسم طب الأسرة,كلية الطب, جامعين حسن الزقازيق, مصر. الخلفية: لقد اتخذت مصر تدابير وقائية استثنائية للسيطرة على "كوفيد-19". ينأثتر امتثال الناس للاستر اتيجيات الوقائية بمعرفتهم ومو اقفه وممارساتهم تجاه المشاكل الصحية. الهدف: قياس المعارف و المو اقف و الممارسات العامة تجاه كوفيد19 بين عامة الناس فى محافظة الثرقية . المنهجية وطرق البحث: اجريت دراسة مقطعية استقصائية في الفترة من 28 مايو إلى 4 يونيه 2020. ثم إنشاء استبيان عبر الإنترنت واستيفائها من قبل المشاركين. وأنجز الاستقصاء سبعمائة وتسعة

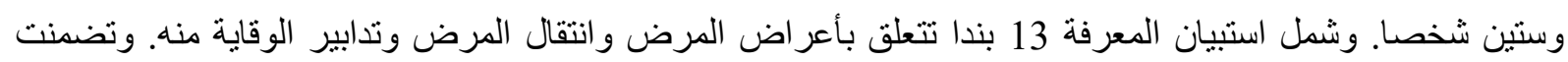
مو اقف المشاركين وممارساتهم أسئلة حول الثقة في الفوز في المعركة ضد مرض كوفين-19 وتدابير غسيل الأبدي المناسبة

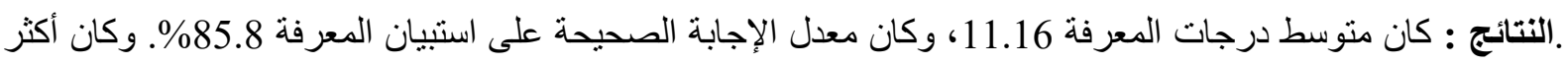
من نصف المشاركين على ثقة من قدرة مصر على الفوز بالمعركة. ويمارس معظمهم إجراءات الغسيل اليدوي المناسبة. وكان متوسط درجات المعرفة أدنى كثير اً بين الفئات الأكبر سناً، و المنخفضة التعليم، والريف، وغير وانير العاملين، و الفئات

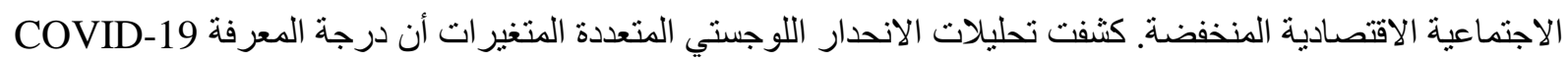
مرتبطة بشكل كبير بانخفاض احتمال المواقف غير المتفائلة والممارسات غير الصحية المتعلقة بـ COVID-19. الخلاصة لاصنة و الأستتتاجات: وبشكل عام، كان المشاركون على مستوى عالٍ من المعرفة، و المو اقف السلبية، والممارسات السليمة فيما

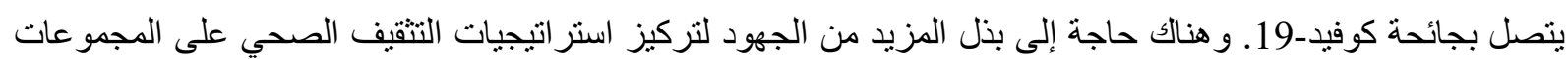
ذات المعرفة المنخفضة التي أظهرتها نتائج الدراسة. 